\title{
Pemetaan Potensi Wisata Halal Di Kabupaten Sumenep, Jawa Timur, Indonesia
}

Fredy Kurniawan, Adi Soeprijanto, Harus Laksana Guntur, Mahendra Wardhana, Imam Abadi, Sayyida

Institut Teknologi Sepuluh Nopember Surabaya

Universitas Wiraraja, Sumenep

fredy@chem.its.ac.id

\begin{abstract}
Abstrak
Kegiatan pariwisata adalah satu hal untuk mendukung daerah dan pembangunan ekonomi negara, melalui valuta asing, pendapatan pajak, dan pungutan lainnya. Indonesia adalah salah satu negara dengan populasi Muslim terbanyak. Melihat peluang ini, pemerintah Indonesia pada 2012 mulai memperkenalkan pariwisata halal di Indonesia. Sumenep, Jawa Timur, Indonesia memiliki beragam potensi wisata yang dapat dikembangkan menjadi pariwisata halal.

Fokus penelitian ini adalah bagaimana memetakan potensi pariwisata Syariah di Sumenep Metode penelitian ini adalah kualitatif dengan teknikpengumpulan datanya observasi terhadap berbagai destinasi wisata dan pelaku-pelaku usaha di bidang pariwisata Kabupaten Sumenep.

Hasil penelitian ini telah memetakan semua potensi wisata halal di Sumenep, Jawa Timur, Indonesia. Potensi wisata halal di Sumenep yang telah berhasil dipetakan meliputi objek makanan, wisata pantai, wisata senjata tradisional (keris), pusat batik. Sumenep, wisata religi, wisata sejarah dan wisata alam. Hotel dan penginapan juga tersedia sehingga wisatawan dapat merencanakan liburan mereka di waktu yang dïnginkan. Transportasi antar tempat wisata juga dapat diakses dengan mudah. Semua objek wisata termasuk kriteria pariwisata halal. Ini dapat diringkas sebagai paket wisata Halal Sumenep. Potensi ini juga didukung oleh budaya keagamaan masyarakat Sumenep. Pemetaan ini akan memudabkan wisatawan Muslim khususnya untuk mengakses pariwisata halal di Sumenep, Jawa Timur, Indonesia.
\end{abstract}

Kata Kunci : Halal tourism, Sumenep, East Java, Indonesia. 


\section{PENDAHULUAN}

Wisata merupakan sebuah kegiatan ketika melakukan perjalanan diluar lingkungan tinggal seseorang dalam jangka waktu tertentu dengan tujuan utama untuk mencari pengalaman atau pendidikan dengan membayar ditempat kegiatan yang dikunjungi(Li et al., 2018; Okumus et al., 2018; Richards, 2018). Konsep pariwisata merupakan serangkaian kegiatan, layanan dan pengalaman tertentu yang diberikan kepada turis yang berkunjung (Battour and Ismail, 2016; Richards, 2018). Tujuan pariwisata memiliki 5 unsur penting yang harus dipenuhi yaitu atraksi, akses, fasilitas, kegiatan dan jasa pariwisata (Hampton and Jeyacheya, 2015; Battour and Ismail, 2016; Li et al., 2018). Konsep wisata juga dijelaskan dalam undang-undang Republik Indonesia nomor 10 tahun 2009 tentang kepariwisataan, dalam UU ini wisata didefinisikan sebagai kegiatan perjalanan yang dilakukan oleh seseorang atau sekelompok orang untuk mengunjungi tempat tertentu dengan tujuan untuk melakukan rekreasi, pengembangan pribadi atau mempelajari keunikan daya tarik wisata yang dikunjungi dalam jangka waktu sementara. Pariwisata merupakan berbagai macam kegiatan wisata dan didukung berbagai fasilitas dan layanan yang disediakan oleh masyarakat, pengusaha dan pemerintah.

Pariwisata di Indonesia merupakan salah satu penunjang pembangunan perekonomian. Kehadiran wisatawan dari mancanegara dan dalam negeri merupakan sumber pendapatan bagi daerah maupun negara dalam bentuk devisa, penerimaan pajak, dan retribusi lainnya. Selain itu, sektor pariwisata juga dapat meningkatkan kesempatan kerja bagi penduduk daerah setempat, meningkatkan pembangunan sarana dan prasarana, meningkatkan industri-industri baru yang berhubungan dengan pariwisata dan memperkenalkan barang-barang produksi lokal sehingga lebih dikenal dunia (Aliah, 2016). Populasi terbesar didunia didominasi oleh kaum muslim dan Indonesia adalah negara muslim terbesar dengan banyak potensi destinasi wisata. Pemerintah menyadari bahwa terdapat peluang baru dalam pariwisata dengan konsep wisata halal, sehingga pada tahun 2012 pemerintah Indonesia mulai memperkenalkan wisata halal di Indonesia (Jafari and Scott, 2014; Firdausi et al., 2017).

Wisata halal didefinisikan sebagai penawaran paket wisata dan destinasi wisata yang secara khusus dirancang untuk melayani wisatawan sesuai kepercayaan muslim(Ryan, 2016). Beberapa komponen yang mendukung wisata halal meliputi makanan halal, transportasi halal, hotel halal, logistik halal, sistem keuangan halal dan paket wisata halal (Battour and Ismail, 2016; Chookaew et al., 2015; El-Gohary, 2016; Samori et al., 2016). Dalam wisata halal, destinasi yang ditunjuk wajib menyediakan makanan halal, akses ketempat ibadah yang mudah, serta akomodasi dan pelayanan yang sesuai standar syari'ah. Produk wisata halal tidak hanya diperkenalkan untuk wisatawan dari timur tengah, negaranegara seperti China, Korea, dan Jepang juga merupakan pasar yang potensial (Chookaew et al., 2015; Firdausi et al., 2017; Nirwandar, 2015; Samori et al., 2016; Yousaf and 
Xiucheng, 2018). Dapat disimpulkan bahwa, wisata halal mampu menarik wisatawan muslim mancanegara dan dalam negeri. Oleh karena itu, wisata halal memiliki prospek yang bagus dan sumber devisa yang menjanjikan dimasa depan (Firdausi et al., 2017).

Dalam mempersiapkan wisata halal di Indonesia pemerintah melalui Kementerian Pariwisata menunjuk beberapa provinsi sebagai destinasi wisata halal. Aceh, Sumatra Barat, Riau, Lampung, Banten, Jakarta, Jawa Barat, Jawa Timur, Jawa Tengah, Yogyakarta, Nusa Tenggara Barat dan Sulawesi Selatan merupakan provinsi yang dipersiapkan menjadi destinasi wisata halal (Nirwandar, 2015). Jawa Timur sebagai salah satu provinsi destinasi wisata halal mempunyai banyak potensi wisata di masing-masing wilayah. Kabupaten Sumenep memiliki sejumlah daerah yang berpotensi untuk dikembangkan sebagai objek pariwisata. Sumenep merupakan salah satu kawasan dipulau Madura yang memiliki banyak objek wisata antara lain wisata alam, wisata budaya dan wisata minat khusus (Ahmad and Kadek, 2013). Akan tetapi, hingga saat ini ketersediaan informasi resmi mengenai panduan wisata halal masih sangat minim terutama untuk wilayah Jawa Timur. Hal ini menyebabkan pelaku wisata masih belum begitu tertarik dengan konsep wisata halal dan hanya sedikit pelaku usaha yang berkecimpung di pariwisata halal. Oleh karena itu untuk mendukung terwujudnya wisata halal di kabupaten Sumenep, pemetaan potensi wisata dianggap penting sebagai langkah awal serta pedoman untuk mengembangkan dan menjalankan wisata halal.

\section{METODE PENELITIAN}

Pemetaan potensi wisata halal di Sumenep ini dilakukan dengan adalah melakukan observasi terhadap berbagai destinasi wisata Kabupaten Sumenep dan pelaku-pelaku usaha di bidang pariwisata. Hasil identifikasi dari data survei akan digunakan untuk melakukan pemetaan wisata halal yang ada di Kabupaten Sumenep. Data sekunder diperoleh dari penelusuran melalui internet. Hasil pemetaan digunakan untuk memberikan saran dan rekomendasi untuk pengembangan wisata halal yang ada d Kabupaten Sumenep. Hasil pemetaan juga akan ditampilkan dalam Artikel Ilmiah.

\section{PEMBAHASAN}

\section{Potensi Wisata Halal Sumenep}

Konsep wisata halal merupakan konsep wisata yang mendapat popularitas tinggi dalam beberapa tahun terakhir. Hal ini disebabkan oleh meningkatnya minat wisatawan muslim pada destinasi wisata internasional. Wisata halal merupakan suatu pasar yang berkembang sangat cepat dalam industri pariwisata. Pasar untuk wisata halal merupakan pasar yang besar karena laju pertumbuhan wisatawan muslim pada tahun 2020 akan mencapai 4,79\% dibandingkan dengan laju pertumbuhan rata-rata 3,8. Hal yang juga harus diperhatikan adalah wisata halal yang mempresentasikan 13\% total wisatawan International. Berdasarkan pada Muslim Index Traveler, keuntungan wisata halal global diperkirakan mencapai angka 300 miliar(Izberk-Bilgin and Nakata, 2016; Jafari and Scott, 2014; Samori et al., 2016; Yousaf and Xiucheng, 2018). Jumlah wisatawan asing yang datang di Indonesia pada tahun 2014 mencapai jumlah 9,3 juta pada 2014, 10,4 juta pada 
tahun 2015 dan diperkirakan akan terus meningkat (Hampton and Jeyacheya, 2015; Nirwandar, 2015; Aliah, 2016; Firdausi et al., 2017). Peningkatan jumlah wisatawan juga terjadi di wilayah Jawa Timur, Data dinas kebudayaan dan pariwisata Jawa Timur sendiri mencatat pada tahun 2017 terdapat 625.729 orang wisatawan mancanegara dan 58.649.178 orang wisatawan domestik yang mengunjungi wilayah Jawa Timur ("Dinas Kebudayaan dan Pariwisata Provinsi Jawa Timur,” 2017).

Meningkatnya jumlah wisatawan dan jumlah destinasi wisata yang banyak menjadi sebuah peluang baru untuk dikembangkannya pariwisata di Sumenep. Kabupaten Sumenep merupakan salah satu dari 4 kabupaten yang ada di Pulau Madura Provinsi Jawa Timur. Kabupaten Sumenep terbagi dalam 27 Kecamatan, 328 Desa dan 4 Kelurahan. Terdapat 126 pulau di Kabupaten Sumenep, 48 pulau berpenghuni dan 78 tak berpenghuni(Ahmad and Kadek, 2013). Kabupaten Sumenep merupakan salah satu daerah yang berpotensi untuk dikembangkan sebagai objek pariwisata. Objek wisata yang banyak membuat kabupaten Sumenep memiliki potensi yang besar sebagai salah satu destinasi wisata baik nasional maupun internasional. Hal ini dapat menjadi salah satu penunjang untuk pembangunan ekonomi di wilayah Sumenep. Kehadiran wisatawan asing dan dalam negeri dapat memberikan pendapatan bagi suatu daerah dalam bentuk devisa, pajak maupun retribusi lainnya. Hal ini tentunya juga akan meningkatkan pembangunan industri-industri baru yang berhubungan dengan pariwisata, meningkatkan lapangan pekerjaan bagi penduduk Sumenep dan memperkenalkan barang-barang maupun suvenir Sumenep kepada dunia.Beberapa objek wisata dan fasilitas transportasi serta penginapan yang terdapat di Sumenep antara lain:

1) Transportasi

Jalur transportasi ke Madura, khususnya menuju kabupaten Sumenep sangat mudah. Para wisatawan yang ingin berkunjung ke Madura, terutama kabupaten Sumenep dapat memilih berbagai macam alat transportasi. Jalur paling mudah adalah dari Surabaya, dimana terdapat berbagai alternatiftransportasi, yaitu:

a. Pesawat

Pulau Madura memiliki satu bandara kecil bernama Bandar Udara Trunojoyoyang terletak di Kabupaten Sumenep, Jawa Timur. Penerbangan yang dilayani merupakan penerbangan perintis, dimana telah ada sejak tahun 2015 oleh PT Susi Pudjiastuti dengan pesawat Susi Air. Rute penerbangan yang tersedia adalah Sumenep-Surabaya dan Sumenep Jember dengan pesawat Cessna Grand Caravan kapasitas 6 penumpang. Pada tahun 2016, PT. Airfast Indonesia melayani rute Sumenep-Surabaya setiap hari Selasa dan Kamis pukul 08.00 WIB dengan pesawat Twin Otter berkapasitas 13 penumpang. Maskapai Lion Wings Air juga telah melayani penerbangan rute Sumenep-Surabaya dan ke berbagai kota sejak 27 September 2017. Rute penerbangan popular dan harga tiket menuju Sumenep dari berbagai kota di Indonesia ditunjukkan pada Gambar 1. 


\section{Gambar 1}

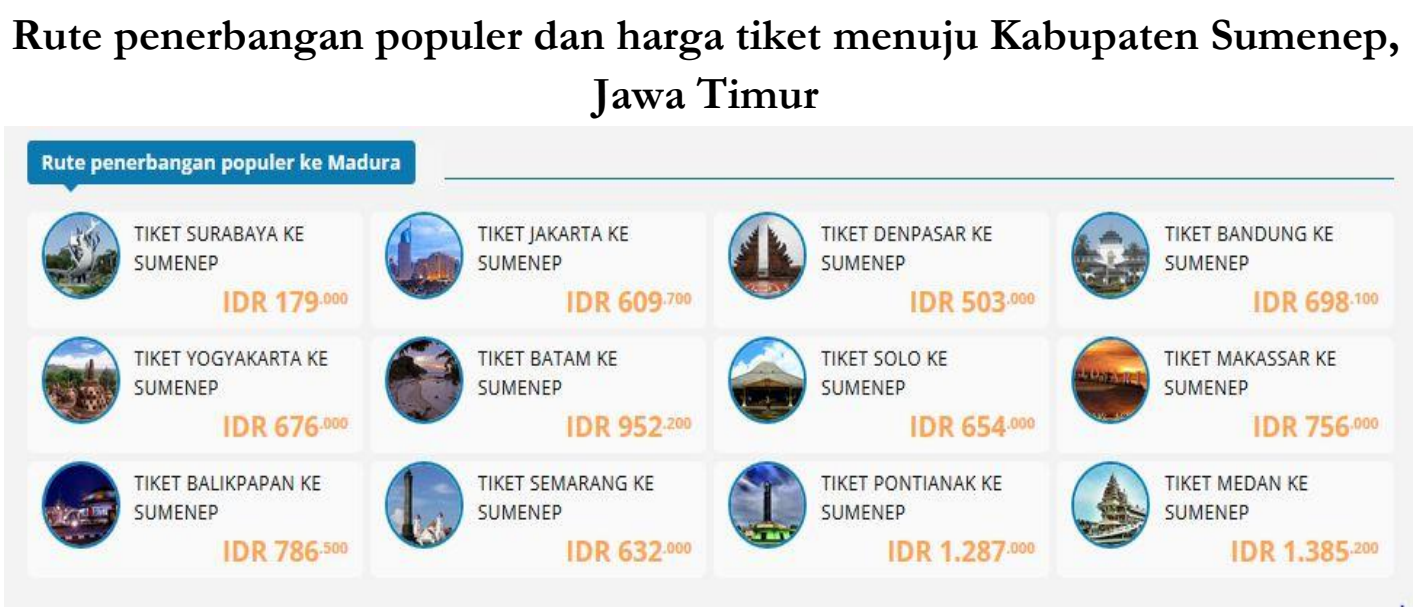

b. Travel

Jenis transportasi ini lebih privat dan tidak terlalu ramai. Jenis mobil yang digunakan biasanya untuk tujuh penumpang denganharga yang cukup ekonomis.

c. Bus

Jenis transportasi ini terdiri dari 2 macam yaitu bus patas dan bus ekonomi. Kendaraan ini merupakan transportasi favorit yang bisa diakses dari terminal Bungurasih. Bus patas memiliki keunggulan seperti lebih cepat, fasilitas lengkap (full AC), dan harga lebih terjangkau dibandingkan travel. Jika ingin transportasi dengan harga lebih murah maka dapat menggunakan bus ekonomi. Namun, waktu tempuh akan lebih lama jika menggunakan bus ekonomi. Hal ini dikarenakan bus ekonomi sering berhenti untuk naik turun penumpang dan berhenti sejenak untuk menunggu penumpang penuh. Fasilitas bus ekonomi juga tidak selengkap bus patas, karena ada yang tidak ber-AC.

d. Kendaraan pribadi

Jenis transportasi lainnya yang bisa digunakan untuk ke Madura adalah kendaraan pribadi berupa motor atau mobil pribadi. Jika menggunakan kendaraan pribadi maka pemilik kendaraan perlu memastikan kendaraannya telah cukup bensin dan dalam kondisi yang baik. Kita dapat melakukan perjalanan dengan santai karena menggunakan kendaraan sendiri dan dapat berhenti atau mampir kemanapun. Selain itu, akses masuk ke Madura melalui jembatan Suramadu saat ini telah digratiskan sehingga jenis transportasi ini paling mudah dan favorit digunakan untuk menuju Madura.

2) Penginapan

Jumlah hotel yang terdapat di Sumenep sebanyak 13 hotel dengan 342 kamar, dengan jumlah ini dapat dikatakan bahwa jumlah hotel di Sumenep sangat terbatas (Sumenepkab.go.id, 2018). Label/sertifikasi halal pada hotel dan penginapan Sumenep masih belum diketahui, untuk itu perlu adanya usaha sosialisasi untuk mengajak para pengusaha di bidang penginapan untuk melakukan sertifikasi dan menerapkan prinsip- 
prinsip Syariah terhadap pengolahan hotel dan penginapan. Beberapa penginapan yang terdapat di Sumenep antara lain; Comfort Room at Family Nur, Jl. Sultan Abdurrahman 1, Sumenep, Hotel C1, Jl. Sultan Abdurahman, Kolor, Kota Sumenep, Hotel Surabaya Sumenep, Jl. Mustika No. 1, Kota Sumenep, Hotel Dubai Sumenep, Jl. Payudan Barat 14.A, Kota Sumenep, Mitraland Hotel, Jl. Trunojoyo 191/ Kota Sumenep, Adhirasa House Sumenep, Jl. Adirasa No 09 Sumenep, Hotel Wijaya I, Jl. Trunojoyo 45-47 Sumenep, Hotel Wijaya II, Jl. Wahid Hasyim No. 3 Sumenep, Pantai Sembilan Seaview, Jl. Pulau Giligenting Sumenep, Gili Labak Homestay Islan, Gili Labak, Kalianget.

2. Wisata Kuliner.

Berdasarkan halaman resmi Dinas Kebudayaan Pariwisata Pemuda dan Olahraga Kabupaten Sumenep, beberapa makanan khas yang dapat dikunjungi adalah rujak Madura, kaldu kokot, Sate gulai, Soto Sabrang, Maco, Keripik Singkong, Rengginang, Apen, Getthas, dan Patthola,

3) Wisata Alam.

Sumenep memiliki beberapa wisata alam antara lain:

a. Pantai Lombang (Gambar 2) yang merupakan objek wisata dengan hamparan pasir putih dan imun pohon cemara. Pantai Lombang terletak sekitar $30 \mathrm{Km}$ dari sebelah timur kota Sumenep.

\section{Gambar 2}

\section{Objek wisata pantai Lombang, Sumenep.}
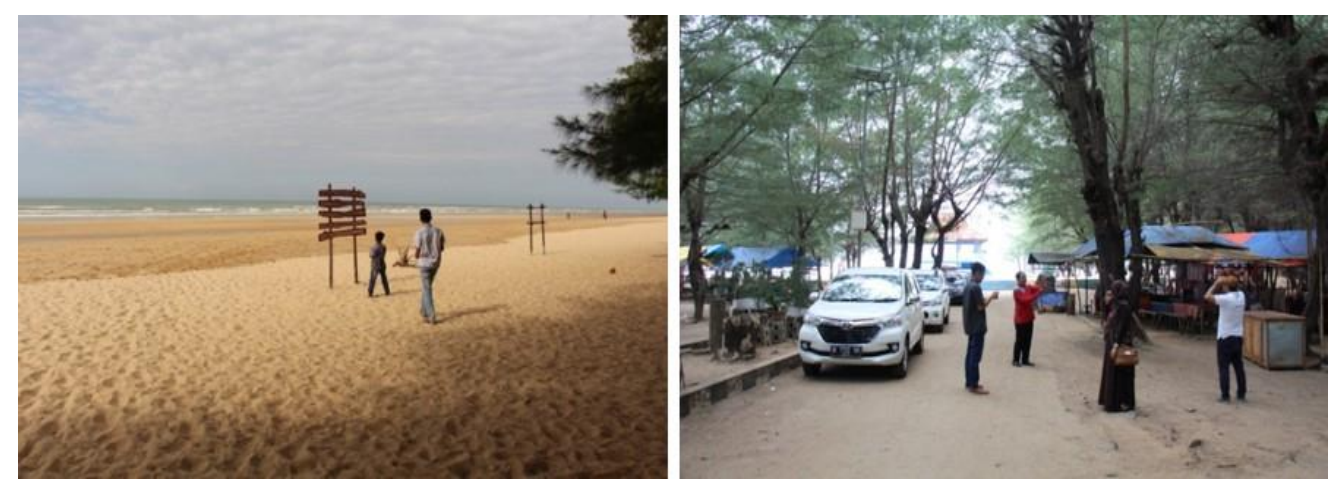

b. Pantai Slopeng, Gunung Pasir, jejeran pohon kelapa sawit dan siwalan yang terletak di $21 \mathrm{Km}$ arah utara kota Sumenep.

c. Pantai Badur (Gambar 3). Pantai ini terletak di Desa Baur Kecamatan Batu Putih.

\section{Gambar 3}

Objek Wisata Pantai Badur, Sumenep.
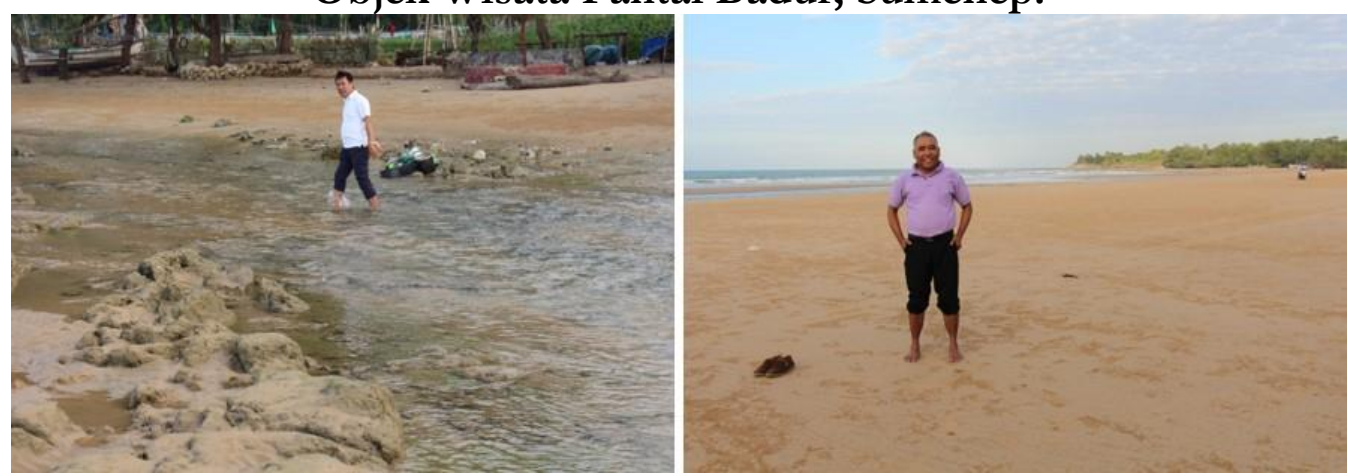
d. Goa Payudan, Goa ini merupakan tempat semedi tokoh terkenal di Madura. Goa Payudan terletak di $30 \mathrm{Km}$ arah barat daya kota Sumenep.

e. Wisata Batu Kapur Putih (Gambar 4).

\section{Gambar 4}
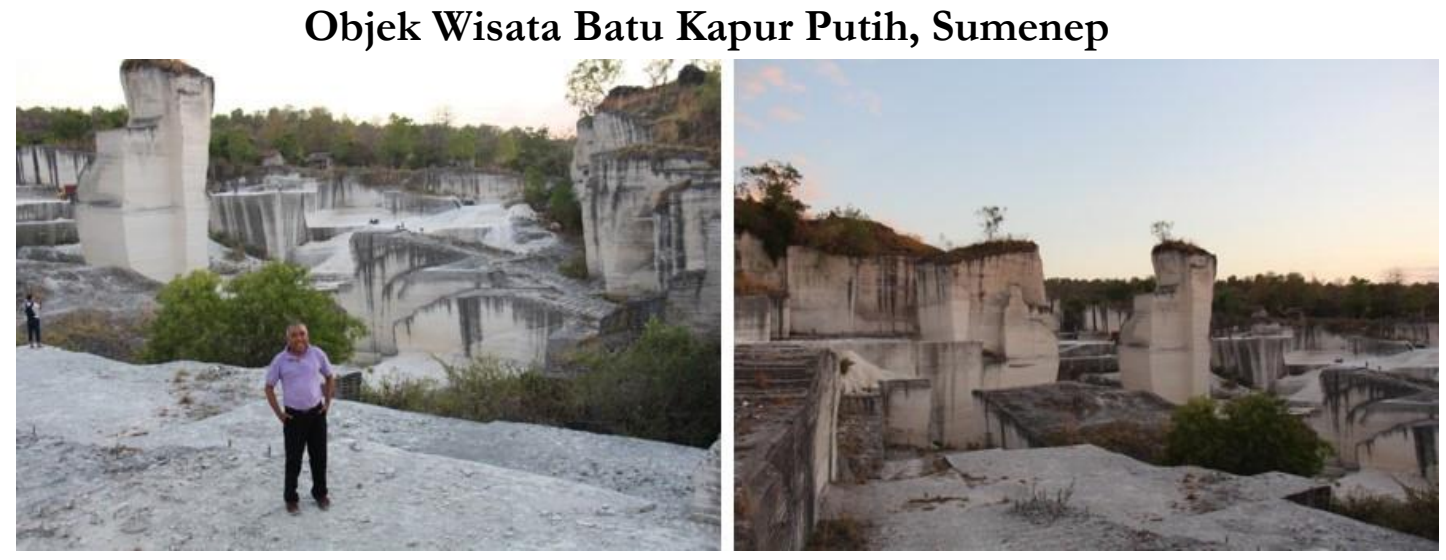

4) Wisata Kepulauan

Sumenep juga memiliki beberapa pulau-pulau kecil yang dijadikan objek wisata, pulau-pulau tersebut antara lain:

a. Pulau Gili Iyang, Pulau ini juga disebut sebagai pulau oksigen yang terletak dikecamatan Dungkek.

b. Pulau Gili Labak, Pulau Gili Labak memiliki potensi wisata terumbu karang yang bagus (bawah laut). Pulau Gili Labak terletak pada $35 \mathrm{Km}$ ke arah timur kota Sumenep.

c. Pulau Gili Genting, Pulau Gili Genting memiliki pantai dengan keunikan pasir yang membentuk angka sembilan. Pulau ini terletak di Desa Bringsang Kecamatan Gili genting.

d. Pulau Mamburit, terletak di Kecamatan Arjasa kepulauan Kangean.

e. Pulau Sapeken, Pulau ini memiliki keindahan terumbu karang dan gunung pasir yang unik. Pulau ini terletak di desa Sapekan.

f. Pulau Kangean, pulau Kangean memiliki 30 buah pulau yang tersebar dipulau Kangean dan pulau Saobi.

g. Pulau Ra'as, Potensi wisata di pulau Ra'as terdiri atas pantai puncak dan wisata bawah laut(terumbu karang) yang indah.

h. Pulau Sepudi, pada pulau Sepudi wisata yang diunggulkan berupa wisata bahari hutan tropis bawah laut dan pantai pesisir yang dilengkapi dengan komunitas mangrove disekitar pulau Sepudi.

\section{5) Wisata Sejarah.}

Kabupaten Sumenep juga memiliki beberapa gedung-gedung peninggalan sejarah, peralatan dan pusaka yang dapat menjadi objek wisata yang menarik wisatawa. Beberapa peninggalan sejarah yang dapat dijadikan objek wisata antara lain.

a. Keraton Sumenep, keraton Sumenep terletak di Desa Pajagalan. Arsitektur keraton yang unik merupakan gabungan arsitektur bergaya Eropa, Arab dan Cina. 
b. Taman Sare, Pemandian putri-putri raja Sumenep pada zaman dulu. Taman Sare terletak di timur Pendopo Agung Keraton Sumenep.

c. Kota Tua Kalianget, merupakan simbol Madura sebagai penghasil garam terbesar di Indonesia.

6) Wisata Religi.

Kabupaten Sumenep memiliki objek wisata religi berupa makam raja-raja atau ulama yang terkenal pada jamannya. Beberapa objek wisata yang dijadikan tujuan wisata religi antara lain,

a. Masjid Jamik, terletak ditengah kota Sumenep. Masjid Jamik merupakan salah satu dari sepuluh masjid tertua di Indonesia.

b. Asta Tinggi, terletak di desa Kebun Agung Kecamatan Batuan. Asta Tinggi merupakan pemakaman raja-raja Sumenep terdahulu.

c. Asta Katandur, asta/pasaran Syekh Ahmad Baidawi yang terletak di Desa Bangkal Kota Sumenep.

d. Asta Jokotole, terletak di dusun Sa-asa Desa Lanjuk Kecamatan Manding.

e. Asta Gumok, terletak didesa Kalimo'aok sebelah tim bandara Trunojoyo, Sumenep.

f. Asta Lor Wetan, terletak di Kelurahan Karangduak.

g. Asta Yusuf, merupakan makam dari seorang penyebar agama Islam di Pulau Talango.

h. Asta K. Faqih, merupakan makam seorang ulama besar bidang ilmu fikih yang terletak di Kecamatan Lenteng.

7) Wisata Edukasi Budaya.

Seni dan budaya Sumenep merupakan karakteristik dan corak masyarakat dapat menjadi daya tarik bagi wisatawan mancanegara dan dalam negeri. Beberapa wisata seni dan budaya yang dapat dikunjungi antara lain.

a. Kerajinan Batik (Gambar 5), salah satu sentra batik tulis di Sumenep terdapat di Desa Pakandangan, Kecamatan Bluto. Salah satu toko penjualan hasil kerajinan batik ditunjukkan pada Gambar 6.

\section{Gambar 5.}

\section{Sentra Kerajinan Batik, Sumenep.}
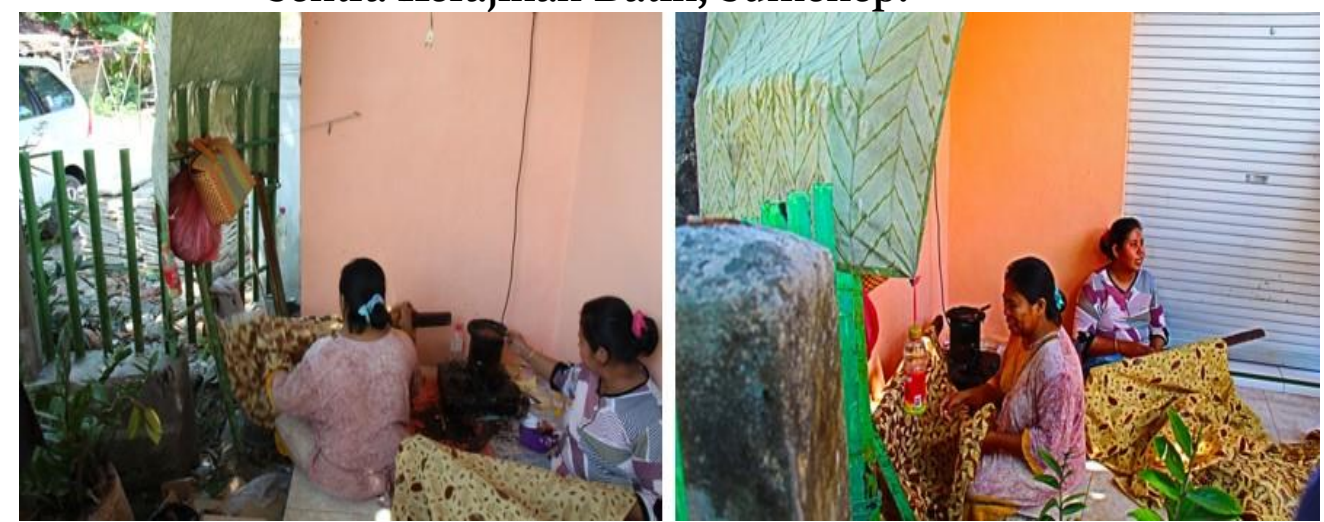


\section{Minur Gurnal \&konomi \& Q Quangan @slam https://journal.trunojoyo.ac.id/dinar/index DOI: https://doi.org/10.21107/dinar \\ Dinar. Vol 6, No 2: Agustus 2018. 1-12 \\ ISSN: 2460-9889 (Cetak) \\ ISSN: 2580-3565 (Online)}

\section{Gambar 6}

Toko Penjualan Batik, Sumenep.

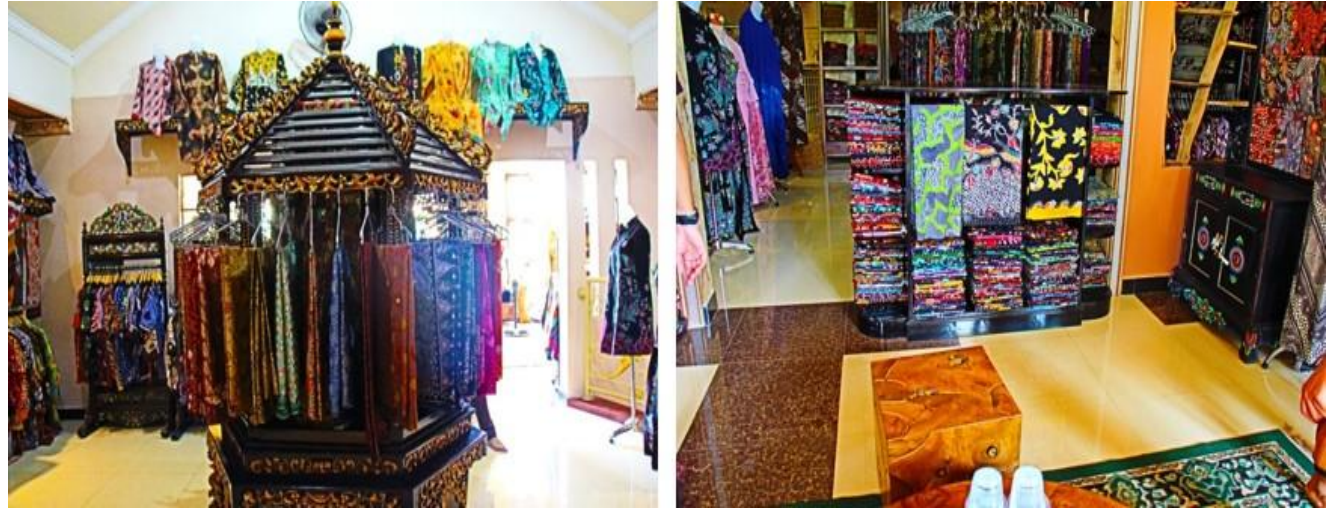

b. Kerajinan Ukiran Topeng, sentra kerajinan topeng dapat dikunjungi di Desa Slopeng, Kecamatan Dasuk.

c. Kerajinan Ukuran Kayu, sentra ukiran kayu dapat dikunjungi di desa Karduluk Kecamatan Pragaan.

d. Kerajinan Keris (Gambar 7), Sentra kerajinan keris terdapat di Desa Aeng Tong Tong Kecamatan Saronggi.

\section{Gambar 7}

Objek Wisata Kerajinan Keris, Sumenep
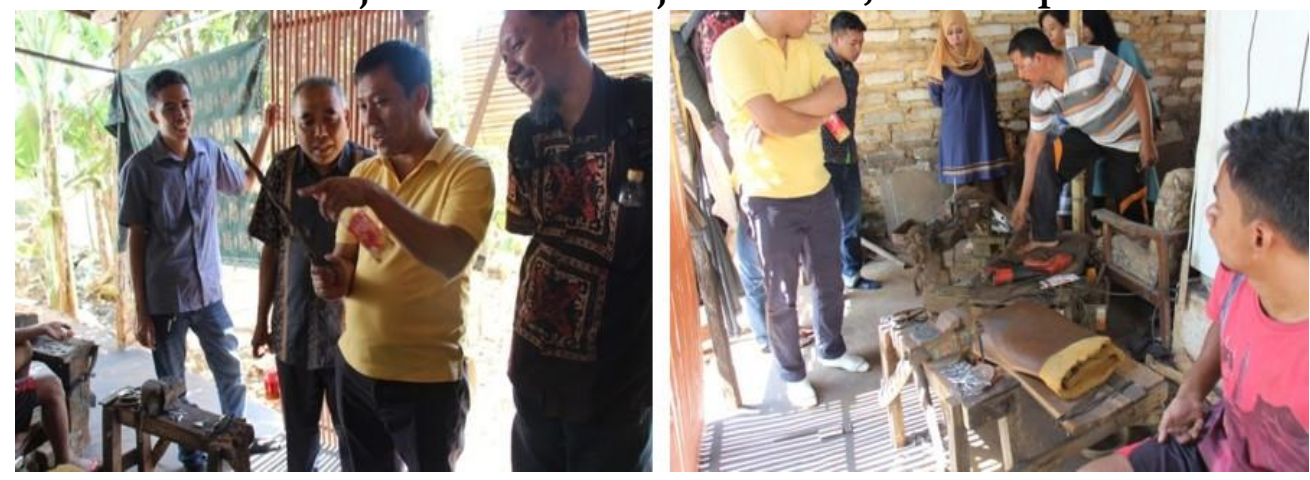

e. Kasur Pasir (Gambar 8), terdapat di Desa Legung Kecamatan Batang-batang.

\section{Gambar 8}

\section{Objek Wisata Desa Pasir, Sumenep.}
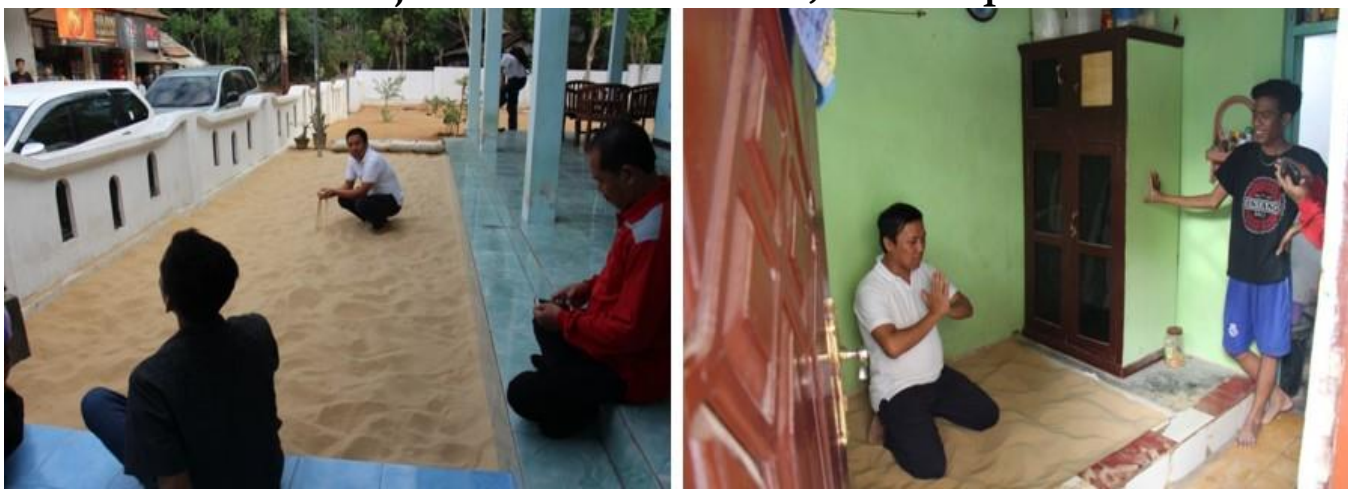
f. Karapan Sapi, Upacara Adat Nyadar, Topeng, Sape Sono', Ludruk, Musik Saronen, Musik Tong-tong/Musik Daul-daul. ("Bappeda Provinsi Jawa Timur," 2018).

Pada tahun 2018, pemerintah Kabupaten Sumenep memiliki rencana untuk mengemas pariwisata di Sumenep dengan konsep wisata halal. Hal ini disampaikan oleh bupati Sumenep, A Busyro Karim. Sumenep yang kaya dengan destinasi wisata meliputi wisata alam, budaya, religi dan bahari. Pengembangan wisata halal di Kabupaten Sumenep akan berfokus pada restoran, hotel dan sarana umum lainnya (Ahmad and Kadek, 2013). Tersedianya objek wisata dan dukungan dari pemerintah membuat kabupaten Sumenep memiliki potensi yang besar untuk dikembangkan sebagai destinasi wisata halal untuk turis nasional maupun mancanegara.Sucipto and Andayani, (2014) menyusun dan merangkum sebuah panduan untuk aplikasi wisata Syariah, beberapa panduan Destinasi Wisata Syariah adalah Destinasi wisata meliputi wisata alam, budaya dan buatan, Fasilitas ibadah yang layak dan suci, pertunjukan seni dan budaya serta atraksi yang tidak bertentangan dengan ketentuan pariwisata Syariah, tersedia makanan dan minuman halal, dan Kebersihan sanitasi dan lingkungan yang terjaga.

\section{KESIMPULAN}

Kabupaten Sumenep memiliki potensi yang besar untuk menjadi destinasi wisata halal hal ini didukung oleh tersedianya objek-objek wisata, fasilitas, serta dukungan dari pemerintah untuk mengembangkan wisata halal di kabupaten Sumenep. Potensi yang besar ini perlu diimbangi dengan manajemen yang handal untuk menjadikan Sumenep menjadi destinasi wisata halal. Hal ini meliputi beberapa aspek seperti publikasi, pengaturan paket-paket wisata yang tersusun dengan baik, pengenalan standar pengelolaan tempat wisata dan edukasi masyarakat dalam menerima para wisatawan. Dengan usaha dan perencanaan yang baik maka diharapkan Sumenep akan menjadi pusat perhatian wisatawan lokal dan internasional.

\section{DAFTAR PUSTAKA}

Ahmad, F., Kadek, P., 2013. TRAVEL GUIDE BOOK “THE EPIC JOURNEY OF SUMENEP.” Aliah, A.D.N., 2016. Peran Sektor Pariwisata Dalam Pembangunan Perekonomian Di Indonesia: Pendekatan Social Accounting Matrix (SAM).

Bappeda Provinsi Jawa Timur [WWW Document], 2018. URL http://bappeda.jatimprov.go.id/ (accessed 11.4.18).

Battour, M., Ismail, M.N., 2016. Halal tourism: Concepts, practises, challenges and future. Tourism Management Perspectives 19, 150-154. https://doi.org/10.1016/j.tmp.2015.12.008

Chookaew, S., chanin, O., Charatarawat, J., Sriprasert, P., Nimpaya, S., 2015. Increasing Halal Tourism Potential at Andaman Gulf in Thailand for Muslim Country. Journal of Economics, Business and Management 3, 739-741. https://doi.org/10.7763/JOEBM.2015.V3.277

Dinas Kebudayaan dan Pariwisata Provinsi Jawa Timur [WWW Document], 2017. URL http://www.disbudpar.jatimprov.go.id/ (accessed 11.4.18).

El-Gohary, H., 2016. Halal tourism, is it really Halal? Tourism Management Perspectives 
19, Part B, 124-130. https://doi.org/10.1016/j.tmp.2015.12.013

Firdausi, I., Marantika, S., Firdaus, Z.N., Sajidah, R., 2017. Lombok: Halal Tourism as a New Indonesia Tourism Strategy, in: March 13-15, 2017 Dubai (UAE). Presented at the March 13-15, 2017 Dubai (UAE), HEAIG. https://doi.org/10.15242/HEAIG.H0317447

Hampton, M.P., Jeyacheya, J., 2015. Power, Ownership and Tourism in Small Islands: Evidence from Indonesia. World Development 70, 481-495. https://doi.org/10.1016/j.worlddev.2014.12.007

Izberk-Bilgin, E., Nakata, C.C., 2016. A new look at faith-based marketing: The global halal market. Business Horizons 59, 285-292. https://doi.org/10.1016/j.bushor.2016.01.005

Jafari, J., Scott, N., 2014. Muslim world and its tourisms. Annals of Tourism Research 44, 1-19. https://doi.org/10.1016/j.annals.2013.08.011

Li, J., Xu, L., Tang, L., Wang, S., Li, L., 2018. Big data in tourism research: A literature review. Tourism Management 68, 301-323. https://doi.org/10.1016/j.tourman.2018.03.009

Nirwandar, D.H.S., 2015. Halal Lifestyle In Indonesia 16.

Okumus, F., van Niekerk, M., Koseoglu, M.A., Bilgihan, A., 2018. Interdisciplinary research in tourism. Tourism Management 69, 540-549. https://doi.org/10.1016/j.tourman.2018.05.016

Richards, G., 2018. Cultural tourism: A review of recent research and trends. Journal of Hospitality and Tourism Management 36, 12-21. https://doi.org/10.1016/j.jhtm.2018.03.005

Ryan, C., 2016. Halal tourism. Tourism Management Perspectives 19, 121-123. https://doi.org/10.1016/j.tmp.2015.12.014

Samori, Z., Md Salleh, N.Z., Khalid, M.M., 2016. Current trends on Halal tourism: Cases on selected Asian countries. Tourism Management Perspectives 19, 131-136. https://doi.org/10.1016/j.tmp.2015.12.011

Sucipto, H., Andayani, F., 2014. Wisata Syariah (Karakter, Potensi, Prospek, dan Tantangannya). Grafindo, Jakarta.

Sumenepkab.go.id, 2018. URL sumenepkab.go.id

Tiket pesawat ke Sumenep (SUP) - Temukan \& Bandingkan penawaran terbaik Tiket Pesawat | Nusatrip [WWW Document], 2018. . nusatrip.com. URL /id/tiketpesawat/ke/sumenep_SUP (accessed 11.4.18).

Yousaf, S., Xiucheng, F., 2018. Halal culinary and tourism marketing strategies on government websites: A preliminary analysis. Tourism Management 68, 423-443. https://doi.org/10.1016/j.tourman.2018.04.006 


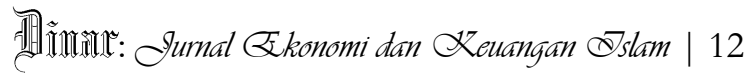

